\title{
Forage Production and Quality of a Mixed-Grass Rangeland Interseeded With Medicago sativa ssp. falcata
}

\author{
Matthew C. Mortenson, ${ }^{1}$ Gerald E. Schuman, ${ }^{2}$ Lachlan J. Ingram, ${ }^{3}$ \\ Venerand Nayigihugu, ${ }^{4}$ and Bret W. Hess ${ }^{5}$ \\ Authors are ${ }^{1}$ Physical Science Technician and ${ }^{2}$ Soil Scientist, High Plains Grasslands Research Station, USDA-ARS, \\ 8408 Hildreth Rd., Cheyenne, WY 82009; ${ }^{3}$ Postdoctoral Fellow, Department of Renewable Resources, \\ Dept. 3354, 1000 E University Ave., College of Agriculture, University of Wyoming, Laramie, WY 82071; and \\ ${ }^{4}$ Assistant Research Scientist and ${ }^{5}$ Associate Professor, Department of Animal Science, Dept. 3684, 1000 E. University Ave., \\ College of Agriculture, University of Wyoming, Laramie, WY 82071.
}

\begin{abstract}
Interseeding alfalfa into rangelands has been assessed for decades as a method of range improvement to increase forage production and forage quality for livestock. Research was initiated in 2001 to examine the long term effects of interseeding yellow-flowered alfalfa (Medicago sativa ssp. falcata) on northern mixed-grass rangelands. Forage production and forage quality parameters were assessed on sites interseeded in 1965, 1987, and 1998 and compared to adjacent native rangelands. Live aboveground biomass for the 1965, 1987, and 1998 interseeded sites was 68,143, and 42\% higher, respectively, compared to their native control areas. Alfalfa aboveground biomass accounted for 1489 of the $2969 \mathrm{~kg} \cdot \mathrm{ha}^{-1}$ live biomass harvested from the 1965 interseeded site, 1940 of the $2744 \mathrm{~kg} \cdot \mathrm{ha}^{-1}$ on the 1987 interseeded site, and 796 of the $2322 \mathrm{~kg} \cdot \mathrm{ha}^{-1}$ on the 1998 interseeded site. Increased soil $\mathrm{N}$ resulting from $\mathrm{N}$ fixation by the alfalfa significantly increased the crude protein $(\mathrm{CP})$ content of several native species, whereas the alfalfa itself provided forage with 16 to $18 \%$ CP. Alfalfa had higher protein degradability and provided higher concentrations of calcium $(\mathrm{Ca})$, potassium $(\mathrm{K})$, and magnesium $(\mathrm{Mg})$ than the native rangeland grasses. This research has shown that the practice of interseeding yellow-flowering alfalfa into rangelands is sustainable over decades and will increase forage production and improve nutritive value of forage in the northern Great Plains.
\end{abstract}

\section{Resumen}

La intersiembra de alfalfa en pastizales ha sido evaluada por décadas como un método de mejoramiento el pastizal para incrementar la producción y calidad del forraje disponible para el ganado. La investigación inició en 2001 para examinar los efectos a largo plazo de las intersiembras de "Yellow-flowered alfalfa" (Medicago sativa ssp. falcata) en pastizales mixtos del norte. Los parámetros de producción y calidad del forraje se evaluaron en sitios con intersiembras realizadas en 1965, 1987, y 1998 y se compararon con pastizales nativos adyacentes. La biomasa aérea viva para los sitios intersembrados en 1965, 1987, y 1998 fue 68, 143, y $42 \%$ mayor, respectivamente, en comparación con sus áreas nativas control. La biomasa aérea de la "alfalfa" aportó 1489 de los $2969 \mathrm{~kg} \cdot \mathrm{ha}^{-1}$ de biomasa viva cosechados del sitio intersembrado en 1965,1940 de los $2744 \mathrm{~kg} \cdot \mathrm{ha}^{-1}$ en el sitio intersembrado en 1987, y 796 de los $2322 \mathrm{~kg} \cdot \mathrm{ha}^{-1}$ del sitio intersembrado en 1998. El aumento del $\mathrm{N}$ del suelo, resultante de la fijación de N por la "alfalfa," incrementó significativamente el contenido de proteína cruda (CP) de varias especies nativas, mientras que la alfalfa por si misma suministro forraje con 16 a $18 \%$ CP. La alfalfa tuvo una mayor degradabilidad de la proteína y proveyó concentraciones mayores de calcio $(\mathrm{Ca})$, potasio $(\mathrm{K})$, y magnesio $(\mathrm{Mg})$ que los zacates nativos del pastizal. Esta investigación muestra que la práctica de intersembrar "Yellow-flowered alfalfa" en los pastizales es sostenibles a través de década, se incrementará la producción de forraje y mejorará el valor nutritivo del forraje en las Grandes Planicies del Norte.

Key Words: yellow-flowered alfalfa, rangeland improvement, nutritive value

\section{INTRODUCTION}

Approximately 336 Mha of land in the United States are used for livestock grazing, which includes 161 Mha of rangelands (USDA-NRCS 1994). The Great Plains region of the United States accounts for a large portion of these native rangelands

Mention of a proprietary product does not constitute endorsement of the product by USDA, ARS, the University of Wyoming, or the authors and does not imply its approval to the exclusion of other products that might also be suitable.

Correspondence: Gerald E. Schuman, USDA, ARS, High Plains Grasslands Research Station, 8408 Hildreth Road, Cheyenne, WY 82009. Email: Jerry.Schuman@ars.usda.gov

Manuscript received 17 October 2004; manuscript accepted 18 June 2005. with livestock production contributing significantly to the economy. According to the Spaeth et al. (1998), 67\% of U.S. rangelands could benefit from improved management or restoration to improve forage production.

Increasing available soil $\mathrm{N}$ through fertilization will increase production and has the potential added benefit of improving plant water use efficiency (Power and Alessi 1971; Power 1985). Symbiotic N-fixers such as legumes can be effectively used to add supplemental $\mathrm{N}$ to rangelands (Sheehy 1989).

Legumes, particularly alfalfa, have long been used as forage and hay crops for livestock due to their high protein content resulting from fixed atmospheric dinitrogen $\left(\mathrm{N}_{2}\right)$. This fixed $\mathrm{N}$ is cycled into the soil $\mathrm{N}$ pool through sloughing of roots and nodules, root exudation, and decomposition of aboveground 


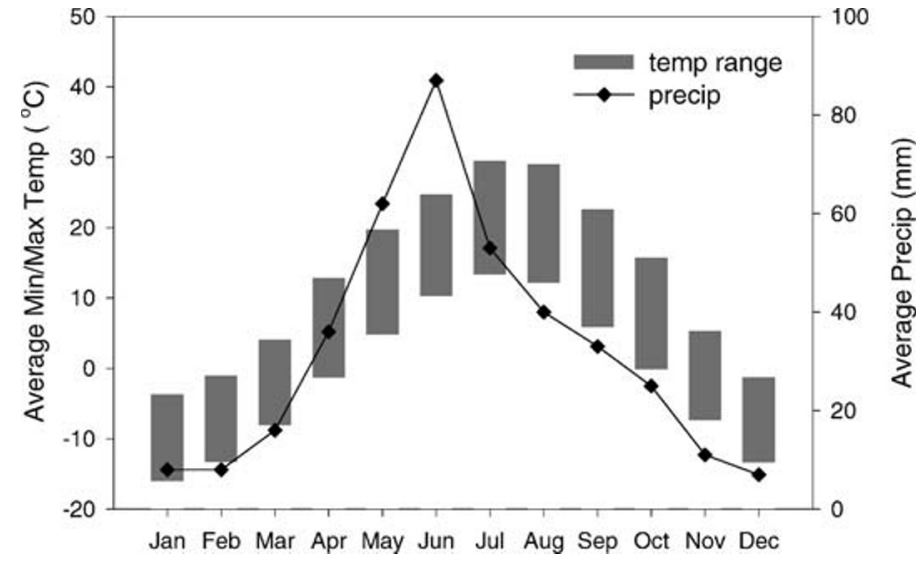

Figure 1. Long-term (1916-2001) monthly temperature and precipitation averages for Hettinger, ND (HPRCC, 2001).

biomass (Lory et al. 1992). Estimates of $\mathrm{N}$ transfer from alfalfa to the surrounding grass vary, with research showing fertilizer equivalent values from 20 to $100 \mathrm{~kg} \mathrm{~N} \cdot \mathrm{ha}^{-1}$, depending on proximity to the alfalfa and the growth habits of the grass (Burity et al. 1989; Leyshon 1985). Brophy et al. (1987) estimated that $68 \%$ of the $\mathrm{N}$ found in grass grown in a systematic planting design with alfalfa came from the transfer of fixed N, representing $17 \%$ of the total amount of $\mathrm{N}$ fixed by the alfalfa component of the plant community.

The process of interseeding alfalfa into rangelands to improve forage production and nutritive value has typically met with limited success due to lack of competitiveness and persistence of the common varieties of alfalfa, especially under grazing (Berdahl et al. 1989). However, yellow-flowered alfalfa (Medicago sativa ssp. falcata; herein called 'falcata') seems well suited for interseeding and grazing in native rangelands. It is characterized by a low set crown which allows it to tolerate grazing, and a fibrous, creeping root system which allows it to spread and compete for shallow moisture with native grasses (Berdahl et al. 1989).

Scientists at the High Plains Grasslands Research Station in Cheyenne, Wyoming became aware of the success of interseeding and grazing 'falcata' alfalfa in a native rangeland environment (Smith 1997). A chronosequence of interseeding dates (1965, 1987 , and 1998) was chosen to evaluate the effect of interseeding 'falcata' alfalfa on forage production, forage quality, soil $\mathrm{N}$ cycling, and soil carbon sequestration. The objectives of this research was to determine if interseeded yellow-flowering alfalfa in northern mixed-grass rangelands would enhance overall forage production and forage quality, and to assess these effects on a series of interseeding dates ranging from 4 to 36 years old.

\section{METHODS AND MATERIALS}

The study site is located on the Smith Ranch near Lodgepole, in Perkins County, South Dakota $\left(45^{\circ} 48^{\prime} 30^{\prime \prime} \mathrm{N}, 102^{\circ} 35^{\prime} 0^{\prime \prime} \mathrm{W}\right)$. The ranch consists of approximately 3650 ha of rangelands and improved pastures. Elevation ranges from 750 to $874 \mathrm{~m}$ and consists of rolling hills and small streams draining toward Lodgepole Creek to the south. Annual precipitation averages $380 \mathrm{~mm}(1916-2001)$, average maximum temperature is $13.1^{\circ} \mathrm{C}$, and the summer frost-free period averages 114 days (90\% chance that the daily minimum temperature will be above $0^{\circ} \mathrm{C}$ ). Climate data are from Hettinger, North Dakota, $22 \mathrm{~km}$ north of the Smith Ranch (HPRCC 2001). Average monthly minimum/maximum temperatures and average precipitation are shown in Figure 1.

Soils at the three interseeding sites were: 1998-Amor loam (fine, loamy, mixed, super active, frigid, Typic Haplustoll) with average native forage production of $2100 \mathrm{~kg} \cdot \mathrm{ha}^{-1} ; 1987-$ Reeder loam (fine, loamy, mixed, super active, frigid, Typic Argiustoll) with average native production of $2100 \mathrm{~kg} \cdot \mathrm{ha}^{-1}$; and 1965-Vebar sandy loam (coarse, loamy, mixed, super active, frigid, Typic Haplustoll) with an average native production of $2300 \mathrm{~kg} \cdot \mathrm{ha}^{-1}$ (USDA-SCS 1977). The dominant plant types on these rangeland sites are cool-season grasses such as western wheatgrass (Pascopyrum smithii [Rydb.] A. Löve), warm-season grasses such as blue grama (Bouteloua gracilis [H.B.K.] Lag. ex Steud.), sedges (Carex sp.), and perennial and annual forbs.

Interseeding on the Smith Ranch was performed using a modified chisel plow implement equipped with standard $25 \mathrm{~cm}$ V-shaped sweeps, with a small metal bar welded just above the sweep at the point of attachment, to clear a furrow in the native sod approximately $15 \mathrm{~cm}$ wide and $2 \mathrm{~cm}$ deep. A seedbox with a double disk opener was mounted directly behind each sweep which planted the alfalfa seed in the center of the furrow about $1.2 \mathrm{~cm}$ deep. The modified implement interseeded two rows spaced $152 \mathrm{~cm}$ apart at approximately $0.5 \mathrm{~kg} \mathrm{PLS} \cdot \mathrm{ha}^{-1}$. The sites selected for this study were interseeded with a 'falcata' blend (Foster) or 'falcata' in 1965, 1987, and 1998. The 1965 site has alfalfa plants with mixed flower colors and the 1987 and 1998 sites are composed of nearly $100 \%$ yellow-flowering 'falcata' alfalfa.

Cow-calf pairs were grazed on the interseeded pastures so each site was grazed only once during a year. Grazing period was adjusted to ensure that an average of $60 \%$ of the annual forage production was utilized (T. Smith, personal communication, 2005) on the pastures interseeded in 1965 and 1998. The 1965 site was grazed in the spring (mid-April through May), the 1998 pasture was grazed in the late summer (August), and the 1987 site was grazed in late fall and winter (December through February). The interseeded pastures also contained large areas of native, undisturbed vegetation, and livestock were free to graze both the native and interseeded areas.

Because of inherent soil and aspect differences and grazing times between interseeded pastures, each planting year was designed as a separate experiment set in a restricted randomized design. Randomization was restricted because interseeding took place in 1965, 1987, and 1998 and the sampling design was established to fit the existing plantings. For each interseeded pasture (year), twelve $40 \mathrm{~m}$ transects were established, with four on the planted rows, four in the interspace between the planted rows and four on an immediately adjacent, untreated native rangeland control area (Fig. 2). Two transects were placed on a single planted row and two on an adjacent row $152 \mathrm{~cm}$ apart and designated legume transects (Legume 1-4). Similarly, four transects were placed between the planted rows and designated as interspace transects (Interspace 1-4). Finally, four transects were designated as control transects (Control 1-4) and located on the native rangeland as near as possible to the planted area while ensuring no interseeding effects from the alfalfa. 
Direct counts of alfalfa plants were performed using a $1 \mathrm{~m}^{2}$ quadrat along the legume and interspace transects to determine alfalfa plant density for each of the planting years and to assess the spread of alfalfa into the interspace area. After counting the number of alfalfa plants in the quadrat, the quadrat was flipped and counted until a $10 \mathrm{~m}^{2}$ area had been assessed. This process was then repeated in another section of the transect so that $20 \mathrm{~m}^{2}$ were evaluated along each legume and interspace transect. No density measurements were performed in the control transects as they were chosen to be free of alfalfa.

Plant mass was estimated by erecting two exclosures $(1 \times 1$ $\mathrm{m})$ on each transect to prevent grazing and clipping two 0.18 $\mathrm{m}^{2}$ quadrats $(30 \times 60 \mathrm{~cm})$ in each exclosure. The quadrats were placed perpendicular to the transects such that the interseeded row bisected the $60-\mathrm{cm}$ side of the quadrat on the legume transects, whereas the quadrats on the $S$ transects represent the center $60 \mathrm{~cm}$ of the $152 \mathrm{~cm}$ interspace. Placement of the quadrats in this manner covered 120 of the $152 \mathrm{~cm}$ row spacing with nearly equal representation (harvest area) of the row and the interspace area (Figure 2). This allowed us to calculate a mean of the legume and interspace transects to represent the entire interseeded area.

Vegetation sampling was performed mid-July, 2001, to coincide with peak standing crop of the native plant community. The alfalfa was at approximately $30-40 \%$ bloom stage at the time of sampling. The vegetation was clipped at ground level and grouped by general plant types: annual forbs, perennial forbs, alfalfa, cool-season perennial grasses, warm-season perennial grasses, other grasses, weedy grasses, standing dead, and litter. Plant samples were placed in paper bags and dried to a constant weight at $60^{\circ} \mathrm{C}$ to estimate aboveground biomass.

When present in sufficient quantity for analysis, plant samples were ground to pass a 40 mesh screen, then further ground to pass a 60 mesh screen using a roller grinder. These samples were analyzed for total $\mathrm{N}$ and $\mathrm{C}$ by dry combustion using a Carlo-Erba C/N analyzer (Nelson and Sommers 1982). If available, a subsample was then ashed at $550^{\circ} \mathrm{C}$ and the ash digested in $6 \mathrm{~N} \mathrm{HCl}$ for determination of total phosphorus $(\mathrm{P})$, calcium $(\mathrm{Ca})$, magnesium $(\mathrm{Mg})$, potassium $(\mathrm{K})$, and sodium (Na) concentrations (Jackson 1958). Plant $\mathrm{P}$ was determined using the vanadomolybdophosphoric yellow color method (Jackson 1958), and the cations were determined by flame atomic absorption spectrophotometry (Rhoades 1982).

In vitro determination of true dry matter disappearance (TDMD) and ruminally degradable protein (RDP) were performed on alfalfa, perennial forbs, cool-season grass, and other grasses from the three interseeded areas and their respective controls. Assays were performed in ANKOM DaisyII incubators (ANKOM Technology, Fairport, New York). The modified McDougall's buffer described by ANKOM was inoculated with rumen fluid (2:1 ratio) collected from ruminally cannulated cows consuming bromegrass hay. Filter bags (ANKOM F57 filter bags; $25 \mu \mathrm{m}$ pore size) containing $0.5 \mathrm{~g}$ of sample were incubated for 4, 8, 12, 16, 24, 48, and $96 \mathrm{~h}$. After removal, bags were rinsed in neutral detergent solution using an ANKOM200 fiber analyzer (ANKOM Technology) to correct for microbial contamination (Mass et al. 1999). Residues were then analyzed for total N (LECO FP-528 Nitrogen Determinator) content to estimate RDP. Although no single in vitro method will work for all situations (Judkins et al. 1990), Holden (1999) showed that

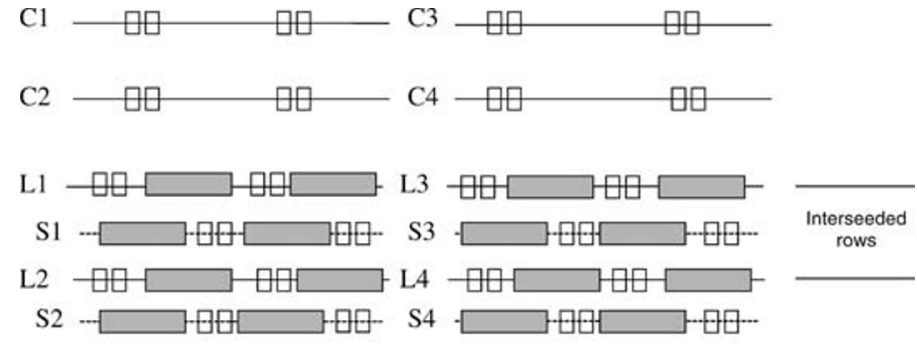

Figure 2. Experimental design showing location of sampling transects in the control $(\mathrm{C})$, legume $(\mathrm{L})$, and interspace $(\mathrm{S})$ areas on one interseeding treatment on the Smith Ranch, Lodgepole, SD, 2001. Approximate locations of $10 \mathrm{~m}^{2}$ belt transects (shaded rectangles) to assess alfalfa stand density and $0.18 \mathrm{~m}^{2}$ quadrats (open rectangles) for plant sample collection for biomass evaluation and forage nutritive value analyses.

results obtained from the in vitro system used in our study were comparable to the standard, bench top methods.

Analysis of variance was used to evaluate the effects of alfalfa interseeding on forage mass and forage nutritive value. Each interseeding date was treated as a separate experiment in a restricted randomized design with two treatments. In the interest of consistency and because it was unknown when a uniform density of alfalfa plants was achieved, biomass and plant chemical data from the seeded row and interspace area were averaged for all interseeding dates. This average represents the entire interseeded treatment area and is compared to the control area. Statistical comparisons of TDMD and RDP were made to compare similar forages in the interseeded vs. control areas, as well as across forage groups in the interseeded areas only to assess the nutritive value of interseeded alfalfa vs. native forages. Statistical analysis was accomplished using the SAS statistical package with least significant difference methods used to identify significant differences between treatment means $(P \leq 0.10)$ (SAS Institute 1999).

\section{RESULTS AND DISCUSSION}

\section{Alfalfa Density}

Alfalfa plant density measurements showed that the older interseeding sites (1965 and 1987) had established a uniform stand of alfalfa over the entire interseeded area (along the interseeded rows and in the interspace areas). The 1965 site had 5.9 and 5.2 plants $\mathrm{m}^{-2}$ for the $\mathrm{L}$ and $\mathrm{S}$ transects, respectively, with the 1987 site having 4.4 plants $\mathrm{m}^{-2}$ for both the legume and interspace transects. Alfalfa density in the planted row (legume transects) in the 1998 site was 2.2 plants $\mathrm{m}^{-2}$ with no spreading into the interspaces (interspace transects) evident at the time of sampling. Because 'falcata' spreads by seed and root proliferation, it can be assumed that the 1998 site will eventually establish a uniform cover of alfalfa similar to the other two interseeding dates.

\section{Forage Mass}

Forage mass data for 2001 represents a slightly below normal precipitation year; therefore, production during average precipitation years might be expected to be higher than that 
Table 1. Plant biomass data of live and dead plant material sampled on Medicago sativa ssp. falcata interseeded rangeland at three interseeding dates by treatment, Smith Ranch, Lodgepole, South Dakota, 2001.

\begin{tabular}{|c|c|c|c|c|c|c|}
\hline \multirow[b]{2}{*}{ Biomass source } & \multicolumn{2}{|c|}{1965} & \multicolumn{2}{|c|}{1987} & \multicolumn{2}{|c|}{1998} \\
\hline & Control & Interseeded & Control & Interseeded & Control & Interseeded \\
\hline & - & 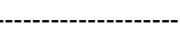 & ----------- & $(S D)$ & ( & 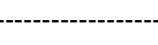 \\
\hline \multicolumn{7}{|l|}{ Live Biomass } \\
\hline Alfalfa & & $1489(1096)$ & & 1940 (935) & & $796(335)$ \\
\hline Annual forbs & $5(5)$ & $6(4)$ & $17(27)$ & $5(6)$ & $5(5) b$ & $31(20) a$ \\
\hline Perennial forbs & $363(315)$ a & $101(97) b$ & $303(166) \mathrm{a}$ & $55(65) b$ & $135(190)$ & $266(143)$ \\
\hline Cool-season grass & $858(522)$ & $403(285)$ & $173(155)$ & $185(117)$ & $476(226)$ & $414(194)$ \\
\hline Warm-season grass & $111(189)$ & $21(18)$ & $22(41)$ & $17(28)$ & $12(19)$ & $11(14)$ \\
\hline Other grasses & $335(335) b$ & $880(448)$ a & $617(201)$ & $542(202)$ & $944(250)$ a & $732(138) b$ \\
\hline Weedy grasses & 99 (115) & $69(64)$ & $0(0)$ & $2(5)$ & $32(66)$ & $71(92)$ \\
\hline Total & $1770(491) b$ & $2969(1353) \mathrm{a}$ & $1131(246) b$ & $2744(1165) \mathrm{a}$ & $1635(396) b$ & $2322(395) \mathrm{a}$ \\
\hline \multicolumn{7}{|l|}{ Dead Biomass } \\
\hline Standing Dead & $588(295)$ a & $270(135) \mathrm{b}$ & $142(66) \mathrm{b}$ & $554(405) \mathrm{a}$ & $610(340)$ & $544(173)$ \\
\hline Litter & $1165(529) b$ & $2117(625) \mathrm{a}$ & $388(158) b$ & $2662(940) \mathrm{a}$ & $1190(327) b$ & $1954(567) \mathrm{a}$ \\
\hline Total Biomass & $3523(1271) b$ & 5356 (1903) a & $1661(328) b$ & 5959 (2006) a & $3435(977) b$ & $4820(835) \mathrm{a}$ \\
\hline
\end{tabular}

Means for each plant type, within a year and between control and interseeded treatments, with different lower case letters are significantly different $(P \leq 0.10)$.

measured in 2001. Precipitation in 2000 and 2001 was 332 and $328 \mathrm{~mm}$, respectively, with the long term average for the area being $380 \mathrm{~mm}$. Increased soil carbon also likely influenced forage mass because of increased soil water holding capacity of the interseeded soil (Mortenson et al. 2004).

Native species live biomass decreased 16, 29, and 7\% in the 1965, 1987, and 1998 interseeded areas, respectively, when compared to their respective control sites; these differences were statistically significant $(P \leq 0.10)$ only for the 1987 site (Table $1)$. This was the result of significantly lower perennial forb mass in the 1987 interseeded area, roughly a six-fold decrease compared to the control area, with no differences in plant mass for the other native plant groups. Perennial forb mass was significantly lower in the 1965 interseeded site as well; however, mass of other grasses was significantly higher in the 1965 interseeded site, resulting in no significant loss of total mass when compared to the native site. Decreases in native plant mass, as well as the high proportion of live biomass from alfalfa in the 1987 interseeded site could be due to grazing management of this pasture. Winter grazing results in the native plant community competing against mature alfalfa for light, water, and nutrients for the entire growing season. Higher alfalfa biomass in the 1987 site compared to the 1965 site supports this hypothesis, even though alfalfa density was lower (Table 1). A summer grazing strategy for the 1987 site would reduce the shading effect on the native plant community by preventing the alfalfa from reaching its full growth potential and likely result in a plant community response similar to that seen in the 1965 site.

Interseeded alfalfa contributed 1489,1940 , and 796 $\mathrm{kg} \cdot \mathrm{ha}^{-1}$ of live aboveground biomass to the total forage mass of the 1965, 1987, and 1998 interseeded sites, respectively (Table $1)$. This resulted in significantly greater total live aboveground biomass for all three interseeding sites compared to their respective control treatments. Nyren et al. (1978) reported average production increases of $27 \%$ when mixed-grass prairie in North Dakota was interseeded with Ladak, Travois, or Vernal alfalfa. This increased production due to the alfalfa translated into $75 \mathrm{~kg} \cdot \mathrm{ha}^{-1}$ more beef production than on the native rangeland (Nyren 1979).

Standing dead biomass was significantly higher in the control than the interseeded area for the 1965 site. Conversely, the control for the 1987 site was significantly lower in standing dead biomass than the interseeded area (Table 1). No treatment differences were observed in the standing dead biomass on the 1998 site. Litter accumulation was significantly lower for the control compared to the interseeded areas for all interseeding dates, with the greatest amount of litter found in the 1987 interseeding site (Table 1). The different grazing strategies used on the three interseeded sites could explain the different amounts of litter and standing dead accumulation. The 1987 site was grazed only in the winter after the alfalfa had matured and dropped its leaves, leaving only coarse woody stems, which are then broken down by cattle movement but probably not consumed due to their low palatability. Alfalfa in the other sites was utilized during the growing season, which reduced the amount of alfalfa biomass that became standing dead and litter. The C:N ratio of the standing dead and litter was lower in the interseeded sites as a result of the increased soil and plant $\mathrm{N}$ content resulting from the legume $\mathrm{N}$ contributions to the system (Mortenson et al. 2004).

Total aboveground biomass, including litter, standing dead, and live plant material, was significantly lower in the control compared to the interseeded area for all three interseeding dates (Table 1). Total biomass was nearly evenly split between live material and dead material in all sites except the 1987 control area.

Some of the common weedy grasses that can be found in these rangelands are downy brome (Bromus tectorum L.) and Japanese brome (Bromus japonicus Thunb. Ex Murr.). No significant weed invasion was observed, as a result of interseeding, on any of the interseeding dates. These weedy grass species in the 1965 site comprised less of the live biomass in the interseeded area 
Table 2. Nitrogen ( $\mathrm{N}$ ) concentrations and total $\mathrm{N}$ mass of live plant and litter material sampled on Medicago sativa ssp. falcata interseeded rangeland at three interseeding dates by treatment, Smith Ranch, Lodgepole, South Dakota, 2001.

\begin{tabular}{|c|c|c|c|c|c|c|}
\hline \multirow[b]{2}{*}{ Plant Type } & \multicolumn{2}{|c|}{1965} & \multicolumn{2}{|c|}{1987} & \multicolumn{2}{|c|}{1998} \\
\hline & Control & Interseeded & Control & Interseeded & Control & Interseeded \\
\hline & & 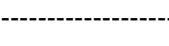 & ----- \% & atter (SD) ---- & 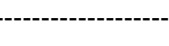 & 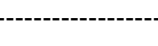 \\
\hline \multicolumn{7}{|l|}{ Live Biomass } \\
\hline Alfalfa & - & $2.77(0.20)$ & - & $2.60(0.15)$ & - & $2.55(0.26)$ \\
\hline Annual forbs & $2.05(0.42) b$ & $2.69(0.03) \mathrm{a}$ & $1.89(0.00) b$ & $2.38(0.17) \mathrm{a}$ & $2.85(0.25)$ & $2.53(0.38)$ \\
\hline Perennial forbs & $1.61(0.19) b$ & $1.98(0.25) \mathrm{a}$ & $1.62(0.15) b$ & $1.90(0.37) \mathrm{a}$ & $1.90(0.35)$ & $1.96(0.43)$ \\
\hline Cool-season grass & $1.42(0.21) b$ & $1.58(0.14) \mathrm{a}$ & $1.39(0.11) b$ & $1.66(0.21) \mathrm{a}$ & $1.48(0.11)$ & $1.45(0.10)$ \\
\hline Warm-season grass & $1.52(0.09) b$ & $1.72(0.17) \mathrm{a}$ & $1.31(0.21) b$ & $1.65(0.07) \mathrm{a}$ & $1.44(0.17) b$ & $1.74(0.16) \mathrm{a}$ \\
\hline Other grasses & $1.39(0.26) b$ & $1.66(0.16) \mathrm{a}$ & $1.26(0.13) b$ & $1.67(0.12) \mathrm{a}$ & $1.50(0.08) b$ & $1.59(0.10) \mathrm{a}$ \\
\hline Weedy grasses & $1.41(0.22)$ & $1.52(0.11)$ & - & - & $1.47(0.07) \mathrm{a}$ & $1.29(0.10) b$ \\
\hline \multicolumn{7}{|l|}{ Dead Biomass } \\
\hline Standing dead & $1.10(0.12) b$ & $1.30(0.07) \mathrm{a}$ & $0.84(0.14) b$ & $1.08(0.18) \mathrm{a}$ & $1.09(0.08)$ & $1.11(0.11)$ \\
\hline Litter & $1.55(0.17) \mathrm{b}$ & $1.93(0.21) \mathrm{a}$ & $0.97(0.14) b$ & $1.73(0.22) \mathrm{a}$ & $1.45(0.12)$ & $1.49(0.16)$ \\
\hline & & & -5 & $a^{-1}(S D)-------$ & & \\
\hline Live Biomass* & $26.3(5.6) b$ & $64.5(18.4) \mathrm{a}$ & $15.9(2.8) b$ & $63.7(10.0) \mathrm{a}$ & $24.3(4.9) \mathrm{b}$ & $44.5(5.9) \mathrm{a}$ \\
\hline
\end{tabular}

Means for each plant type, within a year and between control and interseeded treatments, with different lower case letters are significantly different $(P \leq 0.10)$.

${ }^{*} \mathrm{~N}$ mass calculated using the concentration of $\mathrm{N}$ and the total live biomass harvested.

$(2.4 \%)$ than in the control $(5.6 \%)$. Weedy species made up less than $1 \%$ of the live biomass in the 1987 and $3.1 \%$ of the live biomass in the 1998 interseeding.

\section{Forage Nutritive Value}

Alfalfa N concentrations ranged from 2.6 to $2.9 \%(6.25 \times[\mathrm{N}]$ used to estimate $\mathrm{CP}$ ), which translates to crude protein $(\mathrm{CP})$ levels of 16 to $18 \%$. Most of the native grasses, by comparison, had $\mathrm{N}$ concentrations of 1.3 to $1.7 \%$ (CP of 8.1 to $10.6 \%$ ) at time of harvest in mid-July (Table 2).

The additional soil $\mathrm{N}$ inputs from the interseeded alfalfa are evident in increased $\mathrm{N}$ concentrations of many of the native plant groups in the interseeded areas compared to their respective control treatments. The interseeded legume increased soil total $\mathrm{N}$ levels by an average of $24 \%(6-51 \%)$ in the $1-\mathrm{m}$ soil profile (Mortenson et al. 2004). Significant increases in plant $N$ concentrations were observed in most live plant groups in the 1965 and 1987 interseeding sites as a result of $\mathrm{N}$-fixation by the alfalfa. The warm-season and other grasses in the 1998 site, which represented about $50 \%$ of the native live biomass for that interseeding date, exhibited significant $\mathrm{N}$ increases in the interseeded area over the control after just three years (Table 2).

Higher $\mathrm{N}$ concentrations in live plant biomass (native species and alfalfa) has resulted in significantly higher $\mathrm{N}$ concentrations in the litter material in the 1965 and 1987 interseeded areas compared to their respective untreated areas (Table 2). As a result, the litter C: $\mathrm{N}$ ratio for the 1965 site was 28:1 in the control area compared to $22: 1$ in the interseeded area, and the litter C:N ratio for the 1987 native control area was 43:1 compared to $27: 1$ in the interseeded area. Lowering the C: $\mathrm{N}$ ratio of the plant residue enhances decomposition and cycling of nutrients, with $\mathrm{C}: \mathrm{N}$ ratios of less than 25:1 recommended for net $\mathrm{N}$ mineralization to occur (Paul and Clark 1989). Alfalfa biomass, along with higher $\mathrm{N}$ concentrations, resulted in significantly more live biomass $\mathrm{N}$ in the interseeded areas of all three sites compared to their controls (Table 2). Increased forage production and improved forage nutritive value translates into increased livestock carrying capacity for these rangelands.

Forage nutritive value of alfalfa and the dominant grass types (cool-season and other grasses) was compared to the National Research Council (NRC 1996) nutrient requirements for beef cattle. Interseeded alfalfa met or exceeded all NRC requirements for beef cattle for $\mathrm{CP}$ and had higher $\mathrm{CP}$ content than the native grasses in the interseeded and control treatments (Table 3). At the time of sampling, native forbs and grasses on all interseeding sites generally met the NRC requirements for CP, with the native forbs and grasses growing with alfalfa being significantly higher in CP on the 1965 and 1987 interseeding sites than the control areas. The other grasses component of the 1998 interseeded area was significantly higher in CP than in the control area. Plant P concentrations of the alfalfa and native forbs and grasses in both the interseeded and untreated areas were very near the NRC requirements at time of sampling (Table 3). Miles (1969) concluded that alfalfa interseeded into native rangeland in southcentral Montana increased organic matter buildup and soil fertility, which translated into better rangeland forage quality.

The interseeded alfalfa provided forage that was higher in $\mathrm{Ca}$, $\mathrm{K}$, and $\mathrm{Mg}$ than most of the untreated area native plant groups (Table 3). The influence of the alfalfa on native plant nutrient concentrations is also evident in some instances. Potassium and $\mathrm{Mg}$ concentrations were significantly higher in the perennial forbs and cool-season grasses in the 1965 interseeded area compared to the control. Potassium concentrations of the other grasses were significantly higher for all three interseeding treatments compared to their controls (Table 3).

In vitro determination of TDMD and RDP showed little consistency in the treatment effect of interseeded alfalfa within the dominant native plant groups used for analysis. Native biomass nutritive value was never significantly lower in the interseeded treatments compared to their control areas, with significant increases in TDMD and RDP occurring sporadically 
Table 3. Nutrient data of live plant material sampled on Medicago sativa ssp. falcata interseeded rangeland at three interseeding dates by treatment, Smith Ranch, Lodgepole, South Dakota, 2001.

\begin{tabular}{|c|c|c|c|c|c|c|}
\hline \multirow[b]{2}{*}{ Plant type } & \multicolumn{2}{|c|}{1965} & \multicolumn{2}{|c|}{1987} & \multicolumn{2}{|c|}{1998} \\
\hline & Control & Interseeded & Control & Interseeded & Control & Interseeded \\
\hline & ------------. & 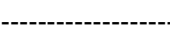 & ----------\% & atter (SD)---- & ------------------ & 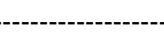 \\
\hline \multicolumn{7}{|l|}{ Alfalfa } \\
\hline Crude Protein (CP) & $N D *$ & $17.3(1.2)$ & ND & $16.3(0.9)$ & ND & $15.9(1.6)$ \\
\hline Phosphorus (P) & ND & $0.21(0.02)$ & ND & $0.15(0.01)$ & ND & $0.17(0.02)$ \\
\hline Calcium (Ca) & ND & $1.13(0.13)$ & ND & $1.16(0.18)$ & ND & $1.46(0.16)$ \\
\hline Potassium (K) & ND & $1.44(0.05)$ & ND & $1.40(0.10)$ & ND & $1.41(0.06)$ \\
\hline Magnesium (Mg) & ND & $0.27(0.03)$ & ND & $0.29(0.04)$ & ND & $0.35(0.04)$ \\
\hline \multicolumn{7}{|l|}{ Perennial Forbs } \\
\hline $\mathrm{CP}$ & $\mathbf{1 0 . 1}(1.2) \mathrm{b}$ & $12.4(1.5) \mathrm{a}$ & $10.1(1.0) b$ & $11.9(2.3) \mathrm{a}$ & $11.9(2.2)$ & $12.3(2.7)$ \\
\hline$P$ & $0.18(0.03) b$ & $0.23(0.03) \mathrm{a}$ & $0.25(0.03) \mathrm{a}$ & $0.15(0.01) b$ & $0.30(0.04) \mathrm{a}$ & $0.26(0.04) b$ \\
\hline $\mathrm{Ca}$ & $0.64(0.20)$ & $0.76(0.20)$ & $0.78(0.15)$ & $0.97(0.51)$ & $\mathbf{0 . 6 0}(0.22)$ & $0.88(0.35)$ \\
\hline $\mathrm{K}$ & $1.13(0.27) b$ & $1.68(0.39) \mathrm{a}$ & $1.80(0.25)$ & $1.52(0.32)$ & $1.85(0.59)$ & $2.22(1.06)$ \\
\hline $\mathrm{Mg}$ & $0.22(0.07) b$ & $0.32(0.10) \mathrm{a}$ & $0.30(0.05)$ & $0.31(0.10)$ & $0.35(0.14)$ & $0.34(0.14)$ \\
\hline \multicolumn{7}{|l|}{ Cool-season Grasses } \\
\hline $\mathrm{CP}$ & $8.9(1.3) \mathrm{b}$ & $9.9(0.88) \mathrm{a}$ & $8.7(0.7) b$ & $10.4(1.3) \mathrm{a}$ & $9.3(0.7)$ & $9.1(0.7)$ \\
\hline$P$ & $0.12(0.02) b$ & $0.14(0.02) \mathrm{a}$ & $0.15(0.02) \mathrm{a}$ & $0.11(0.01) b$ & $0.15(0.01) a$ & $0.13(0.01) b$ \\
\hline $\mathrm{Ca}$ & $0.19(0.05)$ & $0.21(0.02)$ & $0.25(0.02)$ & $0.25(0.06)$ & $0.16(0.03) b$ & $0.20(0.02) \mathrm{a}$ \\
\hline $\mathrm{K}$ & $0.61(0.22) b$ & $\mathbf{0 . 8 9}(0.19) \mathrm{a}$ & $0.53(0.06) b$ & $0.86(0.14) a$ & $0.68(0.12)$ & $0.71(0.09)$ \\
\hline $\mathrm{Mg}$ & $0.08(0.02) b$ & $0.11(0.01) \mathrm{a}$ & $0.11(0.01)$ & $0.12(0.04)$ & $0.10(0.01)$ & $0.10(0.01)$ \\
\hline \multicolumn{7}{|l|}{ Other Grasses } \\
\hline $\mathrm{CP}$ & $8.7(1.6) b$ & $10.4(1.03) \mathrm{a}$ & $7.9(0.8) b$ & $10.4(0.8) \mathrm{a}$ & $9.4(0.5) b$ & $9.9(0.66) \mathrm{a}$ \\
\hline$P$ & $0.12(0.03)$ & $0.15(0.02)$ & $0.10(0.02)$ & $0.10(0.01)$ & $0.12(0.01)$ & $0.12(0.01)$ \\
\hline $\mathrm{Ca}$ & $0.27(0.12)$ & $0.29(0.06)$ & $0.41(0.08)$ & $0.37(0.06)$ & $\mathbf{0 . 3 6}(0.08)$ & $0.40(0.04)$ \\
\hline $\mathrm{K}$ & $0.57(0.16) b$ & $0.97(0.26) \mathrm{a}$ & $0.58(0.09) b$ & $1.08(0.22) \mathrm{a}$ & $0.80(0.26) b$ & $1.10(0.33) \mathrm{a}$ \\
\hline $\mathrm{Mg}$ & $0.11(0.04)$ & $0.13(0.02)$ & $0.16(0.02)$ & $0.14(0.01)$ & $0.18(0.03)$ & $0.16(0.02)$ \\
\hline
\end{tabular}

${ }^{\star} \mathrm{ND}=$ Not determined as no plants present.

Means for each plant type, within a year and between control and interseeded treatments, with different lower case letters are significantly different $(P \leq 0.10)$.

Means in bold type meet NRC nutritional requirements at time of sampling (NRC 1996).

(Tables 4, 5, and 6). The cool-season grasses in the interseeded areas showed significant increases in these quality parameters in roughly $20 \%$ of the analyses, and interseeding affected the other grasses in roughly $30 \%$ of in vitro determinations.

Alfalfa was compared to native species forage in the interseeded areas to assess its contribution to overall forage digestibility. In vitro TDMD analysis of live biomass in the 1965 interseeded area showed that alfalfa and perennial forbs were comparable and higher than the native grasses after $16 \mathrm{~h}$ of incubation. After $24 \mathrm{~h}$, native grasses reached similar levels of TDMD and were significantly higher after $96 \mathrm{~h}$ incubation time (Table 4). For the 1987 and 1998 sites, TDMD ranked perennial forb $>$ alfalfa $>$ native grasses for the first 24 hours of incubation. No differences were seen at $48 \mathrm{~h}$ and $96 \mathrm{~h}$ incubations showed perennial forbs having the highest TDMD and alfalfa the lowest (Tables 5 and 6). Similar trends were evident in the control treatments with perennial forb TDMD generally being greater than cool-season grasses and other grasses (Tables 4, 5 , and 6). Only a few differences in TDMD for a specific forage source were observed between the interseeded and control treatment, and TDMD was always lower in the control treatment for those comparisons (Tables 4, 5, and 6).
In vitro RDP of alfalfa was similar to or higher than native forages, generally ranking alfalfa $>$ perennial forb $>$ native grasses for all interseeding sites, except the $96 \mathrm{~h}$ incubations of plant material from the 1965 site (Tables 4, 5, and 6). In the control treatment, perennial forbs generally showed greater RDP than cool-season grasses and other grasses, when differences existed. Very few differences in RDP were evident between the interseeded and control treatments for a given forage source, but when differences did exist, the control exhibited lower RDP than the interseeded treatment.

Introduction of a high protein plant such as alfalfa into the forage resource was beneficial to this grazing system. Native perennial forbs were similar in nutritive value to alfalfa; however, they made up a small portion of the total live aboveground biomass of the system. Although the presence of interseeded alfalfa doesn't greatly affect digestibility or protein degradation of native forages, the benefits of interseeding are evident in the increase in amount and nutritive value of forage provided by the alfalfa.

Grazing-tolerant alfalfa such as 'falcata' is characterized by slow regrowth after defoliation, but grazing management strategies can be established that could provide additional 
Table 4. In vitro true dry matter disappearance (TDMD) and ruminally digestible protein (RDP) contents of live plant material sampled on Medicago sativa ssp. falcata rangeland, interseeded in 1965, Smith Ranch, Lodgepole, South Dakota, 2001.

\begin{tabular}{|c|c|c|c|c|c|c|c|}
\hline \multirow{2}{*}{$\begin{array}{l}\text { Incubation } \\
\text { time (h) }\end{array}$} & \multirow[b]{2}{*}{ Alfalfa } & \multicolumn{3}{|c|}{ Interseeded } & \multicolumn{3}{|c|}{ Control } \\
\hline & & Perennial forb & Cool-season grass & Other grass & Perennial forb & Cool-season grass & Other grass \\
\hline & 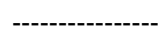 & 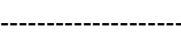 & - & ---- \% TDMD & 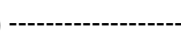 & 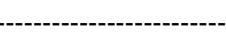 & . \\
\hline 4 & $50.8(3.7) \mathrm{a}$ & $50.2(3.4) \mathrm{a}$ & $31.8(2.7) \mathrm{C}$ & $36.6(2.0) \mathrm{b}$ & $50.7(1.6) \mathrm{a}$ & $30.8(3.0) \mathrm{b}$ & $34.6(1.2) \mathrm{b}$ \\
\hline 8 & $51.4(3.5) \mathrm{a}$ & $50.9(3.0) \mathrm{b}$ & $33.8(2.2) d$ & $37.6(1.9) \mathrm{cd}$ & $51.3(1.7) \mathrm{a}$ & $32.3(2.2) \mathrm{b}$ & $35.6(2.3) \mathrm{b}$ \\
\hline 12 & $52.4(3.9) \mathrm{a}$ & $53.8(1.4) \mathrm{a}$ & $37.5(3.4) \mathrm{c}$ & $43.2(3.4) \mathrm{bA}$ & $53.4(2.8) \mathrm{a}$ & $37.9(2.1) \mathrm{b}$ & $39.2(2.3) \mathrm{bB}$ \\
\hline 16 & $57.4(4.7) \mathrm{a}$ & $55.8(3.8) \mathrm{a}$ & $40.2(2.1) b$ & $44.5(3.1) b$ & $55.2(3.2) \mathrm{a}$ & $41.0(3.3) \mathrm{b}$ & $41.2(1.9) \mathrm{b}$ \\
\hline 24 & $59.4(3.7) \mathrm{a}$ & $57.8(5.9) \mathrm{a}$ & $45.5(5.1) b$ & 53.4 (3.3) aA & $59.4(5.9) \mathrm{a}$ & $45.5(3.2) \mathrm{b}$ & $47.0(2.9) \mathrm{bB}$ \\
\hline 48 & $67.9(2.8)$ & $68.2(4.3)$ & $72.8(3.9)$ & $74.0(3.6)$ & $72.9(8.3)$ & $71.8(1.5)$ & $71.0(2.5)$ \\
\hline 96 & $69.8(3.3) \mathrm{b}$ & $70.9(5.2) \mathrm{b}$ & $78.7(1.6) \mathrm{a}$ & $78.3(2.1) \mathrm{a}$ & $76.9(8.3)$ & $80.2(4.3)$ & $76.9(2.1)$ \\
\hline 4 & $74.2(1.9) \mathrm{a}$ & $58.9(0.6) \mathrm{bA}$ & $50.4(3.2) \mathrm{dA}$ & $51.7(5.9) \mathrm{cdA}$ & $55.0(1.6) \mathrm{aB}$ & $43.0(6.8) \mathrm{bB}$ & $44.6(4.4) \mathrm{bB}$ \\
\hline 8 & $73.4(3.6) \mathrm{a}$ & $60.4(9.3) \mathrm{b}$ & $46.2(2.8) \mathrm{cA}$ & $51.8(6.5) b c$ & $54.3(4.5) \mathrm{a}$ & $39.2(5.2) \mathrm{bB}$ & $46.4(7.1) b$ \\
\hline 12 & $76.6(1.7) \mathrm{a}$ & $65.6(10.0) b$ & $50.6(5.1) b c$ & $57.0(6.5) b$ & $57.2(4.9) \mathrm{a}$ & $47.9(4.2) \mathrm{b}$ & $50.6(6.5) a b$ \\
\hline 16 & $78.5(2.4) \mathrm{a}$ & $68.9(14.8) a b$ & $54.3(1.6) \mathrm{c}$ & $58.5(4.8) b c$ & $64.6(3.3) \mathrm{a}$ & $54.5(5.0) \mathrm{b}$ & $53.8(3.9) \mathrm{b}$ \\
\hline 24 & $82.7(3.1) \mathrm{a}$ & $69.3(17.2) \mathrm{b}$ & $59.5(3.5) b$ & 68.9 (2.7) bA & $68.0(4.5) \mathrm{a}$ & $59.1(4.0) \mathrm{b}$ & 60.3 (3.7) abB \\
\hline 48 & $89.6(0.7) \mathrm{a}$ & $82.6(6.1) b$ & $82.6(1.1) b$ & $83.6(1.5) b$ & $80.5(5.4)$ & $80.1(2.6)$ & $81.2(2.6)$ \\
\hline 96 & $90.6(1.3) \mathrm{a}$ & $85.8(4.1) \mathrm{C}$ & $86.8(0.9)$ bc & 89.5 (1.7) abA & $83.8(5.0)$ & $85.0(4.4)$ & 84.6 (1.1) B \\
\hline
\end{tabular}

Means within an incubation time period and treatment with different lower case letters and means within an incubation time period and plant group between treatments with different upper case letters are significantly different $(P \leq 0.10)$.

late season forage. Dormant range forage is usually deficient in required nutrients for cattle (Krysl and Hess 1993) and protein supplementation, particularly RDP, is critical to the optimal use of these native forages (DelCurto et al. 2000). Thus, management for maximum nutritional value of the interseeded alfalfa could be another benefit of multiple grazing events of an interseeded pasture. Research has shown that timing the last removal of vegetation such that regrowth is near or above $10 \%$ bloom at first frost can result in higher quality winter forage because the new plant material with a greater percentage of leaf material is higher in CP than more mature stems (Collins and Taylor 1980). The risk involved with this is that an early frost, occurring before plants have had sufficient time to regrow and store carbohydrates in the crown and root system, can severely reduce stand density (Collins 1983). In the case of 'falcata,' very little is known about late season morphological changes in

Table 5. In vitro true dry matter disappearance (TDMD) and ruminally digestible protein (RDP) contents of live plant material sampled on Medicago sativa ssp. falcata rangeland, interseeded in 1987, Smith Ranch, Lodgepole, South Dakota, 2001.

\begin{tabular}{|c|c|c|c|c|c|c|c|}
\hline \multirow{2}{*}{$\begin{array}{l}\text { Incubation } \\
\text { time (h) }\end{array}$} & \multirow[b]{2}{*}{ Alfalfa } & \multicolumn{3}{|c|}{ Interseeded } & \multicolumn{3}{|c|}{ Control } \\
\hline & & Perennial forb & Cool-season grass & Other grass & Perennial forb & Cool-season grass & Other grass \\
\hline & & & & ---- \% TDMD & 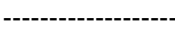 & 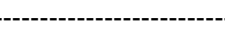 & 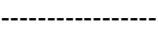 \\
\hline 4 & $57.2(3.0) \mathrm{b}$ & $69.1(0.0) \mathrm{aA}$ & $30.2(1.3) d$ & $39.9(2.0) \mathrm{cA}$ & $61.2(5.9) \mathrm{aB}$ & $28.2(3.9) \mathrm{C}$ & $34.6(2.4) \mathrm{bB}$ \\
\hline 8 & $57.6(3.6) \mathrm{b}$ & $72.0(0.0) \mathrm{aA}$ & $32.1(1.6) \mathrm{d}$ & $40.5(1.2) \mathrm{cA}$ & $64.5(2.0) \mathrm{aB}$ & $31.7(4.6) \mathrm{b}$ & $35.6(2.1) \mathrm{cB}$ \\
\hline 12 & $60.4(3.3) \mathrm{b}$ & $73.7(0.0) \mathrm{a}$ & $38.8(2.3) \mathrm{d}$ & 45.6 (1.6) cA & $68.9(4.5) \mathrm{a}$ & $36.4(2.1) b$ & $40.2(0.9) b B$ \\
\hline 16 & $62.8(5.1) \mathrm{b}$ & $76.4(0.0) \mathrm{a}$ & $39.7(2.4) d$ & $46.1(2.7) \mathrm{cA}$ & $70.9(5.5) \mathrm{a}$ & $38.2(3.4) b$ & $41.2(1.1) b B$ \\
\hline 24 & $65.4(4.7) \mathrm{b}$ & $81.4(0.0) \mathrm{aA}$ & $47.6(2.6) \mathrm{d}$ & 53.5 (3.5) cA & 71.7 (3.1) aB & $46.6(8.8) b$ & $48.2(3.9) b B$ \\
\hline 48 & $73.3(3.6)$ & $83.8(0.0)$ & $70.5(6.3)$ & $69.1(9.5)$ & $80.3(1.4) \mathrm{a}$ & $70.4(3.4) b$ & $72.3(2.6) \mathrm{b}$ \\
\hline 96 & $74.5(3.8) \mathrm{c}$ & $86.1(0.0) \mathrm{aA}$ & $79.0(1.1) \mathrm{b}$ & 77.7 (1.6) bc & 81.5 (1.9) aB & $77.3(0.6) \mathrm{b}$ & $78.9(2.3) \mathrm{b}$ \\
\hline 4 & $74.1(0.7) \mathrm{a}$ & $72.2(0.0) \mathrm{aA}$ & $34.9(1.8) \mathrm{C}$ & $42.6(4.4) \mathrm{b}$ & $62.5(6.3) \mathrm{aB}$ & $33.8(4.5) \mathrm{b}$ & $39.4(3.0) \mathrm{b}$ \\
\hline 8 & $78.1(2.8) \mathrm{a}$ & $80.7(0.0) \mathrm{aA}$ & $44.7(6.4) b$ & 48.3 (3.5) bA & $69.0(2.2) \mathrm{aB}$ & $43.5(3.4) b$ & $42.5(2.4) \mathrm{bB}$ \\
\hline 12 & 79.7 (3.1) a & $81.4(0.0) \mathrm{a}$ & $54.6(4.8) \mathrm{b}$ & 57.7 (7.8) bA & $75.3(4.5) \mathrm{a}$ & $48.4(4.5) b$ & $46.6(1.8) b B$ \\
\hline 16 & $82.7(2.6) \mathrm{a}$ & $83.3(0.0) \mathrm{a}$ & $52.9(3.9) \mathrm{b}$ & 56.7 (7.9) bA & $78.2(5.3) \mathrm{a}$ & $51.1(3.7) b$ & 47.7 (2.4) bB \\
\hline 24 & $85.7(2.2) \mathrm{a}$ & $87.2(0.0) \mathrm{a}$ & 64.3 (4.7) b & $66.5(5.1) \mathrm{bA}$ & $80.4(3.8) \mathrm{a}$ & $59.8(2.6) \mathrm{b}$ & $57.2(4.7) \mathrm{bB}$ \\
\hline 48 & $89.8(0.5)$ & $88.3(0.0)$ & $83.9(3.5)$ & $79.9(8.7)$ & $86.8(2.2) a$ & $79.0(2.4) \mathrm{b}$ & $78.3(2.5) \mathrm{b}$ \\
\hline 96 & $90.7(0.7) \mathrm{a}$ & $90.3(0.0) a b$ & 87.8 (2.1) bA & $85.0(1.8) \mathrm{C}$ & $90.2(1.1) \mathrm{a}$ & $83.3(0.7)$ bB & $84.6(3.4) b$ \\
\hline
\end{tabular}

Means within an incubation time period and treatment with different lower case letters and means within an incubation time period and plant group between treatments with different upper case letters are significantly different $(P \leq 0.10)$. 
Table 6. In vitro true dry matter disappearance (TDMD) and ruminally digestible protein (RDP) contents of live plant material sampled on Medicago sativa ssp. falcata rangeland, interseeded in 1998, Smith Ranch, Lodgepole, South Dakota, 2001.

\begin{tabular}{|c|c|c|c|c|c|c|c|}
\hline \multirow{2}{*}{$\begin{array}{l}\text { Incubation } \\
\text { time (h) }\end{array}$} & \multirow[b]{2}{*}{ Alfalfa } & \multicolumn{3}{|c|}{ Interseeded } & \multicolumn{3}{|c|}{ Control } \\
\hline & & Perennial forb & Cool-season grass & Other grass & Perennial forb & Cool-season grass & Other grass \\
\hline & & & & $\%$ TDMD & & & \\
\hline 8 & $52.9(3.3) \mathrm{b}$ & $66.6(3.7) \mathrm{a}$ & $33.7(2.8) \mathrm{d}$ & $43.8(3.0) \mathrm{C}$ & $64.5(7.6) \mathrm{a}$ & $31.0(1.6) b$ & $40.9(1.7) \mathrm{c}$ \\
\hline 12 & $56.1(4.3) \mathrm{b}$ & $68.6(5.2) \mathrm{a}$ & $37.8(3.1) \mathrm{c}$ & $45.8(3.6) \mathrm{d}$ & $65.4(8.2) \mathrm{a}$ & $33.6(2.0) \mathrm{b}$ & $47.5(10.6) \mathrm{C}$ \\
\hline 16 & $57.7(4.1) b$ & $69.3(5.6) \mathrm{a}$ & $42.1(6.4) \mathrm{cA}$ & $46.4(1.8) \mathrm{C}$ & $67.0(7.2) \mathrm{a}$ & 36.1 (1.1) bB & $44.5(2.3) \mathrm{c}$ \\
\hline 48 & $71.2(7.1)$ & $83.1(6.2) \mathrm{A}$ & $69.7(2.4)$ & $73.2(9.1)$ & $72.5(5.2) \mathrm{B}$ & $66.8(1.2)$ & $71.2(6.5)$ \\
\hline 96 & $74.1(5.7) \mathrm{bc}$ & $84.6(5.4) \mathrm{aA}$ & $78.2(2.0) a b c$ & $80.3(1.1) a b$ & $76.1(5.9) \mathrm{B}$ & $74.8(0.7)$ & $78.8(4.0)$ \\
\hline 4 & $73.3(3.2) \mathrm{a}$ & 65.5 (4.1) ab & $56.2(11.7) \mathrm{bcA}$ & $48.5(3.1) \mathrm{C}$ & $65.1(7.0) \mathrm{a}$ & $48.0(6.5) \mathrm{bB}$ & $48.2(2.6) \mathrm{b}$ \\
\hline 8 & $74.0(3.9) \mathrm{a}$ & $70.0(3.2) \mathrm{a}$ & $54.8(10.2) b$ & $48.1(1.0) \mathrm{b}$ & $68.7(8.9) \mathrm{a}$ & $51.0(4.5) \mathrm{b}$ & $49.0(4.2) \mathrm{b}$ \\
\hline 48 & $91.5(1.6) \mathrm{a}$ & 89.9 (3.2) ab & $82.9(5.5) b c$ & $81.8(6.9)$ bc & $82.9(4.9)$ & $79.1(2.0)$ & $79.7(4.7)$ \\
\hline 96 & $93.1(1.4) \mathrm{a}$ & $91.4(2.1) \mathrm{ab}$ & 87.7 (4.8) bA & $87.5(0.9) b$ & $87.9(2.7)$ & $83.2(1.4) \mathrm{B}$ & $85.7(1.6)$ \\
\hline
\end{tabular}

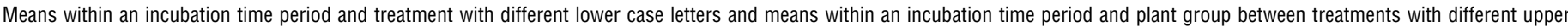
case letters are significantly different $(P \leq 0.10)$.

the plant, and further research is required to evaluate how late in the summer this last removal of vegetation could take place without damaging the plant and diminishing the stand. Additional data on winter forage nutritive value and losses due to leaf drop and nutrient leaching are needed to fully understand the benefits of interseeded 'falcata' on late season forage quality. With the natural hardiness and grazing tolerance of yellow-flowered alfalfa, the practice of interseeding Medicago sativa ssp. falcata into rangelands could potentially be applied to millions of hectares of mixed-grass prairies and possibly to other grazing ecosystems.

\section{MANAGEMENT IMPLICATIONS}

Livestock producers are interested in ways to increase available forage and forage quality on native rangelands, enabling them to increase livestock performance, lengthen the grazing season, and reduce the need for supplemental feed. Forage mass was significantly increased as soon as three years after 'falcata' alfalfa interseeding, and a uniform stand of alfalfa was established within at least 14 years after interseeding. Interseeding 'falcata' alfalfa into these native northern mixed-grass rangelands has enabled ranchers to increase livestock numbers $30 \%$ over the past $10-15$ years (T. Smith, personal communication, 2005). Although some native plant production was lost due to competition for growing season resources when only winter grazed, grazing during the growing season prevented plant community change and production losses of the native species (Mortenson et al. 2004). The observed reduced forage production on the winter grazed pasture (1987 interseeding) could be avoided by rotating pastures that are saved for winter grazing or by early season grazing of those pastures, followed by grazing in the winter. This would also result in better forage quality because the alfalfa would not reach maturity and drop all of its leaves prior to frost. Alfalfa varieties with low crowns and fibrous, creeping root systems survive better under grazing than do tap root types; 'falcata' meets these requirements and has shown long-term sustainability and productivity under well managed grazing in northwestern South Dakota.

\section{ACKNOWLEDGMENTS}

The authors would like to thank Cliff Bowen, Doug Miyamoto, Kristine Partlow, Kellie Sutphin, and Krissie Peterson for their assistance in sample collection and analysis. We would also like to especially thank the Smith family for providing the study site and field assistance.

\section{LITERATURE CITED}

Berdahl, J. D., A. C. Wilton, and A. B. Frank. 1989. Survival and agronomic performance of 25 alfalfa cultivars and strains interseeded into rangeland. Journal of Range Management 42:312-316.

Brophy, L. S., G. H. Heichel, and M. P. Russelle. 1987. Nitrogen transfer from forage legumes to grasses in a systematic planting design. Crop Science 27: 753-758.

Burity, H. A., T. C. TA, M. A. Faris, and B. E. Coulman. 1989. Estimation of nitrogen fixation and transfer from alfalfa to associated grasses in mixed swards under field conditions. Plant Soil 114:249-255.

Coluins, M. 1983. Changes in composition of alfalfa, red clover, and birdsfoot trefoil during autumn. Agronomy Journal 75:287-291.

Collins, M., AND T. H. TAYLOR. 1980. Yield and quality of alfalfa harvested during autumn and winter and harvest effects on the spring crop. Agronomy Journal 72:839-844.

DelCurto, T., B. W. Hess, J. E. Huston, and K. C. Olson. 2000. Optimum supplementation strategies for beef cattle consuming low-quality roughages in the western United States. Proceedings, American Society of Animal Science, 1999. Available at: http://www.asas.org/jas/symposia/proceedings. Accessed 22 May 2000. 
Holden, L. A. 1999. Comparison of methods of in-vitro dry matter digestibility of ten feeds. Journal of Dairy Science 82:1791-1794.

HPRCC. 2001. High Plains Regional Climate Center. Hettinger, ND. (4178). Available at http://www.hprcc.unl.edu/cgi-bin/cli_perl_lib/cliMAIN.pl?nd4178. Accessed 4 May 2002.

Jackson, M. L. 1958. Soil Chemical Analysis. Englewood Cliffs, NJ: Prentice Hall. $498 \mathrm{p}$.

JudkIns, M. B., L. J. KrysL, and R. K. BaRton. 1990. Estimating diet digestibility: a comparison of 11 techniques across six different diets fed to rams. Journal of Animal Science 68:1405-1415.

KRYSL, L. J., AND B. W. HESS. 1993. Influence of supplementation on behavior of grazing cattle. Journal of Animal Science 71:2546-2555.

LeYSHON, A. J. 1985. Nitrogen transfer from alfalfa to grass. In: Proc. soils and crops workshop, Saskatoon, Saskatchewan, Canada. 18-19 February, 1985. Saskatoon, Saskatchewan, Canada: University of Saskatchewan. p. 206215.

Lory, J. A., M. P. Russelle, ANd G. H. Heichel. 1992. Quantification of symbiotically fixed nitrogen in soil surrounding alfalfa roots and nodules. Agronomy Journal 84:1033-1040.

Mass, R. A., G. P. Lardy, R. J. Grant, and T. J. Klopfenstein. 1999. In situ neutral detergent insoluble nitrogen as a method for measuring forage protein degradability. Journal of Animal Science 77:1565-1571.

MiLES, A. D. 1969. Alfalfa as a rangeland legume. Journal of Range Management. 22:205-207.

Mortenson, M. C., G. E. Schuman, and L. J. Ingram. 2004. Carbon sequestration in rangelands interseeded with yellow-flowering alfalfa (Medicago sativa ssp. falcata). Environmental Management 33(supplement): S475-S481.

Nelson, D. W., And L. E. Sommers. 1982. Total carbon, organic carbon, and organic matter. In: A. L. Page (ED.). Methods of soil analysis, Part 2, 2nd ed. Agronomy Monograph 9. Madison, WI: American Society of Agronomy and Soil Science Society of America. p. 539-579.
NRC. 1996. Nutrient requirements for beef cattle. 7th ed. Washington, D.C.: National Academy Press. 248 p.

Nyren, P. E. 1979. Interseeded pasture grazing trial. In: 30th Annual Livestock Research Roundup, Sec. IV, Dickinson Experiment Station, 5 December 1979, Dickinson, ND. p. 7-12.

Nyren, P. E., H. Goetz, and D. Williams. 1978. Interseeding of native mixed prairie in the Great Plains. In: D. N. Hyeder (ED.). Proc. 1st International Rangeland Congress, 14-18 August 1978. Denver, CO: Society for Range Management. p. $636-638$.

Paul, E. A., and F. E. Clark. 1989. Soil Microbiology and Biochemistry. San Diego, CA: Academic Press. 273 p.

PoweR, J. F., AND J. ALESSI. 1971. Nitrogen fertilization of semiarid grasslands: plant growth and soil mineral N levels. Agronomy Journal 63:277-280.

POWER, J. F. 1985. Nitrogen- and water-use efficiency of several cool-season grasses receiving ammonium nitrate for 9 years. Agronomy Journal 77:189-192.

RhoAdes, J. D. 1982. Soluble salts. In: A. L. Page (ed.). Methods of soil analysis, Part 2, 2nd ed. Agronomy Monograph 9. Madison, Wl: American Society of Agronomy and Soil Science Society of America. p. 167-179.

SAS InstituTE. 1999. SAS/STAT user's guide, release 8.0. Cary, North Carolina.

SHeEHY, J. E. 1989. How much dinitrogen fixation is required in grazed grassland? Annals of Botany 64:159-161.

Smith, N. G. 1997. Yellow-blossomed alfalfa on rangeland in South Dakota. Rangelands 19:24-25.

Spaeth, K. E., JR., F. B. Pierson, L. J. Rich, F. Busby, P. L. Shaver, and A. G. MendenHALL. 1998. Summary: State of the nation's non-federal rangelands in the United States: 1992 National Resource Inventory. USDA, NRCS Technical Note. Fort Worth, TX: Grazingland Institute. 115 p.

USDA-NRCS. 1994. Summary Report 1992 National Resources Inventory. USDANRCS. Washington, D.C.: U.S. Government Printing Office. 54 p.

USDA-SCS. 1977. Soil survey of Perkins County, South Dakota. USDA-SCS. Washington, D.C.: U.S. Government Printing Office. 195 p. 